\title{
Microbial diversity in an Oxisol under no-tillage and conventional tillage in southern Brazil ${ }^{1}$
}

\author{
Diversidade microbiana em um Latossolo Vermelho sob plantio direto e convencional \\ no sul do Brasil
}

\author{
Letícia Carlos Babujia², Adriana Pereira Silva ${ }^{3}$, Marco Antonio Nogueira ${ }^{3}$ Mariangela Hungria ${ }^{3 *}$
}

\begin{abstract}
The no-tillage (NT) system of soil management is recognized as more sustainable than conventional tillage (CT), with an important role played by soil microorganisms. The objective of this study was to estimate differences in soil microbial diversity under NT and CT at different soil depths. For that, bacterial (16S rDNA) and fungal (18S rDNA) communities were evaluated by denaturing gradient gel electrophoresis (DGGE) in a 20-year field experiment established on an Oxisol in southern Brazil on which soybean has been grown in the summer and wheat in the winter. Soil samples were collected at the depths of 0-5, 5-10,10-20 and 20-30 cm, and submitted to DGGE analyses. The results revealed lower similarity (28\%) between bacterial communities in the NT and the CT systems at the $0-5 \mathrm{~cm}$ layer. The Shannon index $(\mathrm{H})$ confirmed higher bacterial diversity with NT at all depths, when compared to CT. In relation to fungal communities, higher diversity was detected with CT, especially at the $0-5-\mathrm{cm}$ depth. The results indicate that fungal communities can be more tolerant to environmental stresses related to soil disturbance than bacteria. More emphasis should be given for understanding processes affecting the diversity of microorganisms in agricultural soils, with particular emphasis on tillage systems.
\end{abstract}

Key words: Bacterial diversity. Fungal diversity. PCR-DGGE. Soil tillage.

RESUMO - O sistema de plantio direto (PD) é reconhecido como mais sustentável que o plantio convencional (PC), desempenhando um importante papel na atividade dos microrganismos do solo. O objetivo deste estudo foi estimar diferenças na diversidade microbiana do solo sob PD e PC, em diferentes profundidades. Para isso, foram avaliadas as comunidades bacteriana (16S rDNA) e fúngica (18S rDNA) através da eletroforese em gel com gradiente desnaturante (DGGE), em um experimento de campo estabelecido há 20 anos em um Latossolo Vermelho no sul do Brasil, com a soja cultivada no verão e trigo no inverno. As amostras de solo foram coletadas nas profundidades de $0-5 ; 5-10 ; 10-20$ e 20-30 cm, e foram submetidas a análises de DGGE. Os resultados revelaram baixa similaridade (28\%) na profundidade de 0-5 cm para as comunidades bacterianas entre o sistema de PD e PC. O índice de Shannon $(\mathrm{H})$ confirmou diversidade bacteriana superior no PD em todas as profundidades, quando comparado ao PC. Em relação às comunidades fúngicas, a maior diversidade foi detectada no sistema de PC, especialmente na profundidade de $0-5 \mathrm{~cm}$. Os resultados indicam que as comunidades fúngicas podem ser mais tolerantes a estresses ambientais relacionados com a perturbação do solo que as bactérias. Maior ênfase deve ser dada para compreender os processos que afetam a diversidade dos microrganismos em solos agrícolas, com particular destaque para os sistemas de preparo do solo.

Palavras-chave: Diversidade bacteriana. Diversidade fúngica. PCR-DGGE. Manejo do Solo

\footnotetext{
*Autor para correspondência

'Recebido para publicação em 05/01/2014; aprovado em 10/06/2014

Parte da Dissertação de Mestrado da primeira autora, apresentada ao Programa de Pós-Graduação em Biotecnologia, Universidade Estadual de Londrina

2Departamento de Química, Universidade Estadual de Maringá, Av. Prof. Colombo, nº 5.790, Maringá-PR, Brasil, 87.020-900, leticiacb_@ hotmail.com

32Embrapa Soja, Caixa Postal 231, Londrina-PR, Brasil, 86.001-970, drikapera@yahoo.com.br, marco.nogueira@embrapa.br, mariangela. hungria@embrapa.br
} 


\section{INTRODUCTION}

The adoption of the no-tillage (NT) over the conventional tillage (CT) system has significantly increased worldwide. Brazil is probably the best example of the widespread adoption of NT at over 30 million hectares, accounting for about $70 \%$ of grain production (FEBRAPDP, 2012). Numerous studies have reported improvements in soil-chemical and physical properties due to NT, with an emphasis on erosion control (LAL, 2007), as well as benefits to soil microorganisms, reflecting in higher crop productivity and improved soil quality (KASCHUK; ALBERTON; HUNGRIA, 2010; SILVA et al., 2010). The great majority of these studies have focused on soil microbial biomass (KASCHUK; ALBERTON; HUNGRIA, 2010), specific microorganisms (HANSEL et al., 2008; HUNGRIA et al., 2001), or microbial enzyme activities (BALOTA et al., 2013). However, the combined analyses of several microbial parameters provide better information about the quality and quantity of microbial communities (JOYNT et al., 2006).

Few studies have reported the effects of tillage on the diversity of microbial communities, whereas it is important to understand responsiveness and resilience of microorganisms to management practices and how changes in the composition of soil microorganisms may affect soil quality (WARDLE et al., 1999). Furthermore, recent studies suggest that evaluations of soil microorganisms can show changes in soil quality prior to alterations in physical or chemical parameters (BABUJIA et al., 2010; HUNGRIA et al., 2009; KASCHUK; ALBERTON; HUNGRIA, 2010).

The development of methods for assessing microbial diversity has contributed to our understanding of the structure and functioning of microbial communities in soil. Denaturing gradient gel electrophoresis (DGGE) is increasingly used in studies of microbial ecology, although it has some limitations, e.g. with DGGE-PCR, more-abundant communities sometimes prevail (SMIT et al., 1999), and some fungi or bacteria may generate multiple bands (MUYZER et al., 1993). Therefore, DGGE may be more suitable for comparative studies (MUYZER et al., 1993).

In a previous study of our group, we described quantitative differences between CT and NT at several soil depths, evaluated by the microbial biomass of carbon and nitrogen and microbial activity (basal respiration and microbial quotient, $q$ Mic) (BABUJIA et al., 2010). The objective of this study was to expand our findings by evaluating changes in bacterial and fungal diversity with depth under NT and CT in the same 20-year-old trial. The information contributes to our still-poor knowledge of microbial diversity in soils in Brazil as affected by soil management.

\section{MATERIAL AND METHODS}

\section{Experimental design and soil management}

The experiment was conducted in a Rhodic Eutrudox (Latossolo Vermelho Eutroférrico, Brazilian classification), established in the summer of 1988/89 in Londrina, Paraná state, southern Brazil, located at latitude $23^{\circ} 11^{\prime} \mathrm{S}$ and longitude $51^{\circ} 11^{\prime} \mathrm{W}$, and at an altitude of $620 \mathrm{~m}$. The climate is subtropical humid, with average annual temperature of $21{ }^{\circ} \mathrm{C}$; the average maximum temperature is of $28.5^{\circ} \mathrm{C}$ in February and the minimum of $13.3{ }^{\circ} \mathrm{C}$ in July, respectively. The average annual rainfall is $1,651 \mathrm{~mm}$, with January being the wettest month $(217 \mathrm{~mm})$ and August the driest $(60 \mathrm{~mm})$.

The experiment consists of plots of $7.5 \mathrm{~m}$ wide x $30.0 \mathrm{~m}$ long $\left(225 \mathrm{~m}^{2}\right)$, with four replicates per treatment, arranged in a randomized block design. For this study we used the treatments under two soil management practices: (1) notillage (NT), with sown directly through the residues of the previous crop, with the opening of only a narrow channel line for sowing [ranging from $1.5 \mathrm{~cm}$ to $2 \mathrm{~cm}$ for the wheat (Triticum aestivum L.) and $3 \mathrm{~cm}$ for the soybean (Glycine $\max (\mathrm{L}$.$) Merr.)]; (2) conventional tillage (CT), where the$ soil is prepared annually with a disc plow (plowing varies between 20 and $25 \mathrm{~cm}$ ) and harrow $(15 \mathrm{~cm}$ range). The sequence of soybean in summer and wheat in the winter has always been applied for both NT and CT.

\section{Soil sampling}

At the time of sampling, the experiment was 20 years old. Samples were taken when soybean was at full bloom (R2). Samples were collected at four different depths: $0-5,5-10,10-20$ and $20-30 \mathrm{~cm}$ in the central part of each plot (four replicates per treatment). A trench of 20 $\mathrm{cm}$ wide $\mathrm{x} 50 \mathrm{~cm}$ in length $\mathrm{x} 60 \mathrm{~cm}$ depth was opened, from which the soil samples were collected with a spatula, from the midpoint of each layer and at the four sides of the trench. Subsamples were used to compose a sample of bulk soil (approximately $1.0 \mathrm{~kg}$ ). At the laboratory the samples of each treatment were mixed and sieved ( $<4 \mathrm{~mm}, 5 \mathrm{mesh}$ ) and then stored in plastic bags at $-20^{\circ} \mathrm{C}$ until the analyses.

\section{DNA extraction from soil}

The DNA was extracted from soil samples $(0.25 \mathrm{~g})$ using the soil UltraClean ${ }^{\mathrm{TM}}$ DNA kit (MoBio Laboratories, Inc., California, USA) following the manufacturer's protocol. The concentration of DNA was analyzed in $1 \%(\mathrm{w} / \mathrm{v})$ agarose gel in $1 \mathrm{X}$ TBE, to verify the quantity, the purity and the 
molecular size, using standard DNA lightweight Mass ${ }^{\mathrm{TM}}$ (Invitrogen Life Technologies). The amount of DNA was visually assessed by electrophoresis on agarose gels stained with $0.00005 \%$ ethidium bromide.

\section{Specific PCR conditions for bacterial and fungal communities}

Two successive amplifications were performed for the V3 hypervariable region encoding the 16S rRNA gene. First, the soil DNA was amplified with primers fD1 (5'-AGAGTTTGATCCTGGCTCAG-3') and rD1 (5'-AAGGAGGTGATCCAGCC-3'), as described by Weisburg et al. (1991), which amplify almost the entire region of the DNA encoding the $16 \mathrm{~S}$ rDNA (approximately $1,500 \mathrm{bp})$.

The first PCR reaction consisted of $36.6 \mu \mathrm{L}$ deionized water; $3.0 \mu \mathrm{L}$ dNTPs (deoxynucleotides) 1.5 mmol L-1 $1.5 \mu \mathrm{L} \mathrm{MgCl}_{2} 50.0 \mathrm{mmol} \mathrm{L}^{-1} ; 5.0 \mu \mathrm{L} 10 \mathrm{X}$ buffer (20.0 mmol L-1 Tris-HCl, $\mathrm{pH} 8.4) ; 1.5 \mu \mathrm{L}$ of each primer (fD1 e rD1) 10.0 pmols; $0.2 \mu \mathrm{L} 5 \mathrm{U}$ of Taq DNA polymerase (Invitrogen Corp., Carlsbad, CA) and $1.0 \mu \mathrm{L}$ of extracted soil DNA $(\sim 30 \mathrm{ng})$ in a total volume of $50.0 \mu \mathrm{L}$. The PCR program consisted of: an initial denaturation at $95^{\circ} \mathrm{C}$ for $2 \mathrm{~min} ; 15$ cycles of denaturation at $94{ }^{\circ} \mathrm{C}$ for $15 \mathrm{~s} ; 93{ }^{\circ} \mathrm{C}$ for $45 \mathrm{~s}$; primer annealing at $55^{\circ} \mathrm{C}$ for $45 \mathrm{~s}$, and extension at $72{ }^{\circ} \mathrm{C}$ for 2 min; holding at $4{ }^{\circ} \mathrm{C}$ until removal. The amplification was performed in a thermocycler MJ Research, Inc., model PTC-200.

The second amplification was performed using $1.0 \mu \mathrm{L}(\sim 20 \mathrm{ng})$ of the products of the first reaction as template. The primers F-968, (5'CGCCCGGGGCGCGCCCCGGGCGGGGCGGG GGACGGGGAACGCGAAGAACCT TAC-3') with a GC-clamp (underlined) and R-1401 (5'GCGTGTGTACAAGACCC-3’) (NÜBEL et al., 1996) were used to amplify the $16 \mathrm{~S}$ rDNA region of approximately $430 \mathrm{bp}$, corresponding to the V3 hypervariable region. PCR mixtures were prepared with: $5.0 \mu \mathrm{L}$ dNTPs $1.5 \mathrm{mmol} \mathrm{L}^{-1} ; 1.3 \mu \mathrm{L} \mathrm{MgCl}_{2} 50.0$ mmol L-1; $2.5 \mu \mathrm{L}$ buffer $10 \mathrm{X}$ [20.0 $\mathrm{mmol} \mathrm{L}^{-1}$ Tris- $\mathrm{HCl}$ (pH 8.4)]; $1.0 \mu \mathrm{L}$ of each primer (F-968 and R-1401) 10.0 pmoles; $0.2 \mu \mathrm{L} 5 \mathrm{U}$ of Taq DNA polymerase (Invitrogen Corp., Carlsbad, CA); $1.0 \mu \mathrm{L}$ of the PCR product of the first reaction with $\mathrm{fD} 1$ and $\mathrm{rD} 1$ primers $(\sim 10.0 \mathrm{ng})$; sterile ultrapure water to complete a final volume of $25.0 \mu \mathrm{L}$. The following amplification cycles were used: one initial denaturation cycle at $94{ }^{\circ} \mathrm{C}$ for $2 \mathrm{~min} ; 2$ cycles at $94^{\circ} \mathrm{C}$ for $1 \mathrm{~min}$, at $60^{\circ} \mathrm{C}$ for $2 \mathrm{~min}$, and at $72{ }^{\circ} \mathrm{C}$ for $2 \mathrm{~min} ; 2$ cycles at $94{ }^{\circ} \mathrm{C}$ for $1 \mathrm{~min}$, at $59{ }^{\circ} \mathrm{C}$ for $2 \mathrm{~min}$, and at $72^{\circ} \mathrm{C}$ for $2 \mathrm{~min}, 94^{\circ} \mathrm{C}$ for $1 \mathrm{~min}$, $58^{\circ} \mathrm{C}$ for $2 \mathrm{~min}, 72^{\circ} \mathrm{C}$ for $2 \min (2$ cycles $) ; 94^{\circ} \mathrm{C}$ for 1 $\min , 57^{\circ} \mathrm{C}$ for $2 \min ; 72^{\circ} \mathrm{C}$ for 2 min (2 cycles); $94{ }^{\circ} \mathrm{C}$ for $1 \mathrm{~min}, 56{ }^{\circ} \mathrm{C}$ for $2 \mathrm{~min}, 72{ }^{\circ} \mathrm{C}$ for $2 \min (2$ cycles); $94{ }^{\circ} \mathrm{C}$ for $1 \mathrm{~min}, 55^{\circ} \mathrm{C}$ for $2 \mathrm{~min}, 72^{\circ} \mathrm{C}$ for $2 \mathrm{~min}$; and for $10 \mathrm{~min}$ at $72{ }^{\circ} \mathrm{C}$; holding at $4{ }^{\circ} \mathrm{C}$ until removal. Amplification was confirmed by running $2.0 \mu \mathrm{L}$ of PCR product in a $1 \%(\mathrm{w} / \mathrm{v})$ agarose gel in $1 \mathrm{X}$ TBE, staining with ethidium bromide $\left(0.3 \mu \mathrm{g} \mathrm{mL}^{-1}\right)$ and visualizing under UV light. The products of the amplification were subjected to the DGGE analysis as described by Silva et al. (2013).

The 18S rDNA was amplified with the primers EF4f (5'-GGAAGGGATGTATTTATTAG-3') and EF3r (5'-TCCTCTAAATGACCAGTTTG-3'), as previously described by Smit et al. (1999), generating fragments of approximately $1,500 \mathrm{bp}$. The reactions were carried out with $29.65 \mu \mathrm{L}$ of deionized water; $6.6 \mu \mathrm{L}$ dNTPs $1.5 \mathrm{mmol} \mathrm{L}^{-1} ; 3.75 \mu \mathrm{L} \mathrm{MgCl} 250.0 \mathrm{mmol} \mathrm{L}^{-1} ; 10.0 \mu \mathrm{L}$ $10 \mathrm{X}$ buffer (20.0 mmol L-1 Tris-HCl, $\mathrm{pH} 8.4) ; 1.0 \mu \mathrm{L}$ of primer EF4f (10 pmol); $1.0 \mu \mathrm{L}$ of primer EF3r $(10 \mathrm{pmol})$; $0.6 \mu \mathrm{L}$ of Taq DNA polymerase (5U) and $2.0 \mu \mathrm{L}$ of DNA (approximately $30.0 \mathrm{ng}$ ). The reactions were performed in a thermocycler MJ Research, Inc., model PTC-200, as follows: $94{ }^{\circ} \mathrm{C}$ for $3 \mathrm{~min}$ ( 1 cycle); $94{ }^{\circ} \mathrm{C}$ for $1 \mathrm{~min}, 51{ }^{\circ} \mathrm{C}$ for $1 \mathrm{~min}, 72{ }^{\circ} \mathrm{C}$ for $1 \mathrm{~min}(25$ cycles $) ; 72{ }^{\circ} \mathrm{C}$ for $10 \mathrm{~min}$ (1 cycle); holding at $4{ }^{\circ} \mathrm{C}$ until removal.

For the DGGE analysis, the product of the first PCR reaction was diluted 1:2000 and used as template for a second PCR with primers based on the fungal EF4f and NS3r (5'CGCCCGCCGCGCCCCGCGCCCGGCCCGCGCCCC CGCCCCGGCTGCTGGCACCAGACTTG-3') with a GC-clamp (underlined) (WHITE et al., 1990) to produce fragments of $530 \mathrm{bp}$. The dilution was necessary to ensure the formation of more specific bands. The PCR was performed with $29.65 \mu \mathrm{L}$ of deionized water; $6.6 \mu \mathrm{L}$ dNTPs $1.5 \mathrm{mmol} \mathrm{L}^{-1} ; 3.75 \mu \mathrm{L} \mathrm{MgCl}_{2} 50 \mathrm{mmol} \mathrm{L}^{-1} ; 5.0 \mu \mathrm{L}$ $10 \mathrm{X}$ buffer $\left(20.0 \mathrm{mmol} \mathrm{L}^{-1}\right.$ Tris- $\left.\mathrm{HCl}, \mathrm{pH} 8.4\right) ; 1.0 \mu \mathrm{L}$ of primer EF4f $(10.0 \mathrm{pmol}) ; 1.0 \mu \mathrm{L}$ of primer $\mathrm{NS} 3 \mathrm{r}(10.0$ pmol); $1.0 \mu \mathrm{L}$ of Taq DNA polymerase $(5 \mathrm{U})$ and $2.0 \mu \mathrm{L}$ of the first PCR product diluted. The program used for the second PCR was as follows: initial denaturation at $94{ }^{\circ} \mathrm{C}$ for $4 \min \left(1\right.$ cycle); $94{ }^{\circ} \mathrm{C}$ for $1 \mathrm{~min}, 60^{\circ} \mathrm{C}$ for $1 \mathrm{~min}, 72{ }^{\circ} \mathrm{C}$ for $1 \mathrm{~min}$ (10 cycles); $94{ }^{\circ} \mathrm{C}$ for $1 \mathrm{~min}, 50{ }^{\circ} \mathrm{C}$ for $1 \mathrm{~min}$, $72{ }^{\circ} \mathrm{C}$ for $1 \mathrm{~min}(15$ cycles $)$ and $72^{\circ} \mathrm{C}$ for $5 \mathrm{~min}$ ( 1 cycle); holding at $4{ }^{\circ} \mathrm{C}$ until removal. PCR products were verified by electrophoresis on agarose gel (1.5\%).

\section{Bacterial and fungal analysis using electrophoresis in denaturing gradient gel (DGGE)}

The fragments of $16 \mathrm{~S}$ rDNA were separated in a $6 \%(\mathrm{w} / \mathrm{v})$ polyacrylamide gel (ratio of acrylamide: bisacrylamide, 37.5:1 w/w) denaturing gradient gels containing $35 \%$ to $60 \%$ of urea $(100 \%$ denaturant corresponding to $7 \mathrm{~mol} \mathrm{~L}^{-1}$ urea and $40 \%$ formamide). The gel received $20.0 \mu \mathrm{L}$ of PCR products of the second 
16S rDNA amplification and $10.0 \mu \mathrm{L}$ of loading buffer ( $2 \%$ cyanol bromophenol blue xylene $2 \%$ glycerol and $100 \%$ deionized water). Electrophoresis was performed in a vertical DCode (BioRad) at $0.5 \mathrm{X}$ TAE buffer (10.0 mmol L-1 Tris-acetate and $0.5 \mathrm{mmol} \mathrm{L}^{-1}$ EDTA, $\mathrm{pH} 8.3$ ), with the voltage of $200 \mathrm{~V}$ at $60^{\circ} \mathrm{C}$ for $16 \mathrm{~h}$.

The fragments of $18 \mathrm{~S}$ rDNA were separated in an $8 \%(\mathrm{w} / \mathrm{v})$ polyacrylamide gel (acrylamide: bisacrylamide, $37.5: 1(\mathrm{w} / \mathrm{w})$ containing $30 \%$ to $55 \%$ of urea $\left(100 \%\right.$ denaturant corresponding $7 \mathrm{~mol} \mathrm{~L}^{-1}$ urea and $40 \%$ formamide). Twenty $\mu \mathrm{L}$ of the PCR product and $10.0 \mu \mathrm{L}$ of loading buffer were applied to the gel and then subjected to electrophoresis in the DCode system, as described for the bacterial community, with $1 \mathrm{X}$ TAE buffer, and the voltage of $85 \mathrm{~V}$ at $55^{\circ} \mathrm{C}$ for $17 \mathrm{~h}$.

After electrophoresis, the gels were stained with ethidium bromide solution for $3 \mathrm{~min}$ and visualized under UV light.

\section{Data Analysis}

The PCR-DGGE profiles were analyzed using the Bionumerics software (Applied Mathematics, Kortrijk, Belgium, v.4.6). The similarities between the fingerprints were statistically analyzed using the UPGMA algorithm with the Jaccard coefficient (SNEATH; SOKAL, 1973) and the tolerance index of $5 \%$.

The profiles obtained at each depth and soil management system were also analyzed with the program Spade ("Prediction of species and diversity of estimation") (CHAO; SHEN, 2013) with a sample size of 100 and a cut-off of 4.0. The Shannon-Weaver index of diversity $(\mathrm{H})$ was used to compare changes in diversity of microbial community structure in soils, and calculated using the equation proposed by Shannon and Weaver (1963), where $\mathrm{N}_{i}$ is the height of a peak and $\mathrm{N}$ is the sum of all peak heights of the curve.

$$
\begin{aligned}
& H=-\sum_{i=1}^{s} P_{i} 1 n P_{i}=-\sum_{i=1}^{s}\left(N_{I} / N\right) \ln \left(N_{I} / N\right) \\
& E_{I I}=H / H_{\max }=H / \ln S
\end{aligned}
$$

For each community the ACE index (abundancebased coverage estimator), a non-parametric index proposed by Chao and Lee (1992) was also estimated.

\section{RESULTS AND DISCUSSION}

The PCR-DGGE profiles of the $16 \mathrm{~S}$ rDNA communities showed that some bands were common to all depths, irrespective of the soil-tillage system.
In addition, the $0-5 \mathrm{~cm}$ layer of the NT soil had four dominant bands (more intense bands) that were absent in the CT system. The analysis of the profiles based on band position indicated lower similarity (28\%) between bacterial communities of the NT and the CT systems in the $0-5 \mathrm{~cm}$ layer (Figure 1). For the $5-10$ and $10-20 \mathrm{~cm}$ layers, the similarity between NT and CT was $65 \%$ and in the 20-30 cm layer it was 50\% (Figure 1).

The DGGE profiles of the soil-bacterial communities showed greater diversity, when estimated by the Shannon diversity index, at all depths with NT in comparison to CT (Table 1). For the bacterial

Figure 1 - Similarity dendrogram using the Jaccard coefficient with tolerance of 5\% and the unweighted pair-group method with arithmetic averages (UPGMA) for the $16 \mathrm{~S}$ rDNA and $18 \mathrm{~S}$ rDNA-DGGE profiles of soil bacterial and fungal communities, respectively, at different soil depths, under notillage (NT) or conventional tillage (CT). Profiles for each system and depth are representative of all replicates

\section{S rDNA}

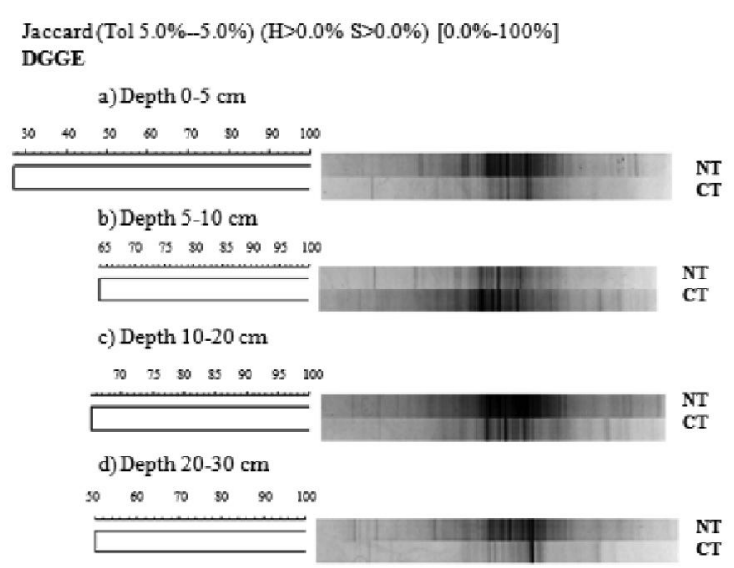

18S rDNA

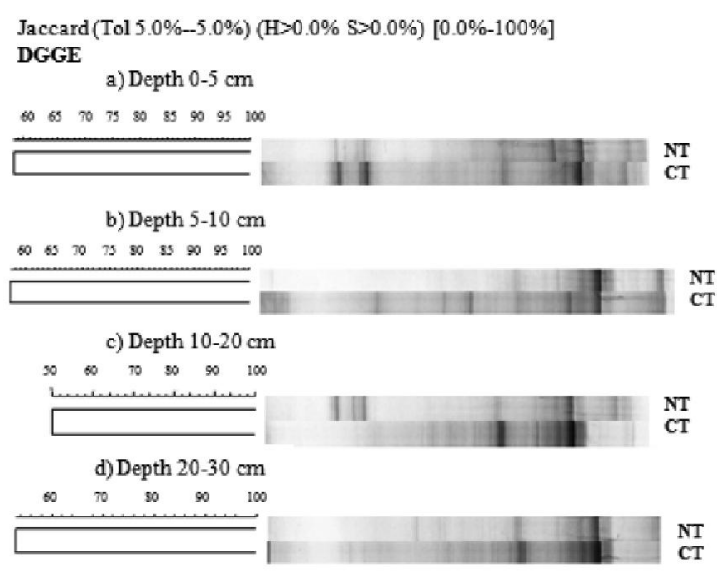


communities, the richness indices (ACE) showed no differences between NT and CT. In relation to the evenness index $(\mathrm{E})$, the values can be considered high in both tillage systems and at all depths; however, the highest value was observed under NT and the lowest under CT, both in the 0-5 cm layer (Table 1).

The PCR-DGGE fingerprints of the $18 \mathrm{~S}$ rDNA region in the $0-5 \mathrm{~cm}$ layer showed two distinct dominant communities (more intense bands), and one non-dominant community (fainter bands) in the CT system that were absent in with NT. The fungal communities were similar
(60\%) between NT and CT at the depths of $0-5 \mathrm{~cm}$ and $5-10 \mathrm{~cm}$ (Figure 1). For the 10-20 and 20-30 cm layers, the similarities were $50 \%$ and $54 \%$, respectively.

The diversity index for the fungal community was higher in the CT than in the NT system, except for the 5-10 cm layer, and the highest diversity was found in the 0-5 cm layer (Table 2). For the NT, no differences in diversity were found at the different depths. The richness indices were also higher in the CT system in the 0-5 and 10-20 cm layers (Table 2). As for bacteria, the evenness indices were high in all treatments, and

Table 1 - Number of DGGE bands and Shannon's diversity index ${ }^{1}(\mathrm{H})$ of soil bacterial community (16S rDNA) as influenced by soil management and depth

\begin{tabular}{lcccc}
\hline \multirow{2}{*}{ Bacterial diversity } & \multicolumn{4}{c}{ No-Tillage (NT) } \\
\cline { 2 - 4 } & $0-5 \mathrm{~cm}$ & $5-10 \mathrm{~cm}$ & $10-20 \mathrm{~cm}$ & $20-30 \mathrm{~cm}$ \\
\hline Shannon Index (H) & $3.288 \pm 0.055$ & $3.099 \pm 0.079$ & $3.340 \pm 0.057$ & $3.232 \pm 0.074$ \\
Richness Index (ACE) & $38.2 \pm 4.9$ & $44.8 \pm 12.4$ & $41.9 \pm 5.5$ & $61.0 \pm 19.3$ \\
Total bands & 29 & 25 & 31 & 28 \\
Evenness (E) & 0.975 & 0.963 & 0.973 & 0.970 \\
\hline \multirow{2}{*}{ Bacterial diversity } & & Conventional Tillage (CT) & $20-30 \mathrm{~cm}$ \\
\hline Shannon Index (H) & $2.649 \pm 0.077$ & $2.811 \pm 0.079$ & $2.936 \pm 0.085$ & $2.966 \pm 0.088$ \\
\hline Richness Index (ACE) & $30.0 \pm 9.9$ & $31.2 \pm 8.0$ & $40.1 \pm 12.9$ & $40.3 \pm 12.3$ \\
Total bands & 20 & 18 & 21 & 22 \\
Evenness (E) & 0.884 & 0.972 & 0.964 & 0.959
\end{tabular}

${ }^{1}$ Values \pm standard error of mean; SPADE settings: $\mathrm{m}=100$ (sample size) and $\mathrm{K}=4$ (cut-off value)

Table 2 - Number of DGGE bands and Shannon's diversity index ${ }^{1}(\mathrm{H})$ of soil fungal community (18S rDNA) as influenced by soil management and depth

\begin{tabular}{lcccc}
\hline \multirow{2}{*}{ Fungal diversity } & \multicolumn{4}{c}{ No-Tillage (NT) } \\
\cline { 2 - 5 } & $0-5 \mathrm{~cm}$ & $5-10 \mathrm{~cm}$ & $10-20 \mathrm{~cm}$ & $20-30 \mathrm{~cm}$ \\
\hline Shannon Index (H) & $2.427 \pm 0.068$ & $2.558 \pm 0.08$ & $2.306 \pm 0.096$ & $2.539 \pm 0.095$ \\
Richness Index (ACE) & $13.8 \pm 1.9$ & $22.6 \pm 6.0$ & $14.9 \pm 3.3$ & $22.0 \pm 5.6$ \\
Total bands & 12 & 14 & 11 & 14 \\
Evenness (E) & 0.977 & 0.969 & 0.962 & 0.962 \\
\hline \multicolumn{1}{c}{ Fungal diversity } & & Conventional Tillage (CT) & $20-30 \mathrm{~cm}$ \\
\cline { 2 - 5 } & $0-5 \mathrm{~cm}$ & $5-10 \mathrm{~cm}$ & $10-20 \mathrm{~cm}$ & $2.558 \pm 0.076$ \\
Shannon Index (H) & $2.807 \pm 0.065$ & $2.546 \pm 0.150$ & $2.654 \pm 0.092$ & $17.3 \pm 2.8$ \\
Richness Index (ACE) & $21.7 \pm 2.8$ & $18.4 \pm 3.4$ & $24.3 \pm 6.8$ & 14 \\
Total bands & 18 & 14 & 16 & 0.969 \\
Evenness (E) & 0.971 & 0.965 & 0.957 &
\end{tabular}

${ }^{1}$ Values \pm standard error of mean; SPADE settings: $\mathrm{m}=100$ (sample size) and $\mathrm{K}=4$ (cut-off value) 
the highest values were found in both tillage systems at the $0-5 \mathrm{~cm}$ depth (Table 2). Although the evenness index showed small variations among treatments (Table 1 and 2), the uniformity of profiles of bacterial and fungal communities implies dominance of a few communities, regardless of soil-tillage system.

Previous studies have shown that microbiological parameters are more sensitive to disturbance than soil chemical and physical parameters and also that NT can substantially increase microbial activity, showing that microorganisms can be used as bioindicators of soil quality (BABUJIA et al., 2010; HUNGRIA et al., 2009; NAKATANI et al., 2011). In one of these experiments, evaluations were performed on the same treatments as in our present study, which detected differences in microbial biomass and activity, as well as in the stocks of soil $\mathrm{C}$ and $\mathrm{N}$ in NT versus $\mathrm{CT}$, and also with depth (BABUJIA et al., 2010). Considering the whole soil profile of $0-60 \mathrm{~cm}$, the NT system resulted in considerably higher microbial biomass of $\mathrm{C}(35 \%)$ and of $\mathrm{N}(23 \%)$ than the CT (BABUJIA et $a l ., 2010)$. Therefore, it was important to investigate whether increased microbial biomass under NT is associated or not with higher microbial diversity. Our study has now shown clear differences between the structures of the bacterial and fungal communities at different depths under NT and CT.

To develop cropping practices that ensure optimal use and protection of soil biodiversity, the main challenge is to predict impacts of tillage systems on soil organisms. As shown in our study, the bacterial diversity was more sensitive than the fungal community to soil disturbances. In the most superficial layer, of $0-5 \mathrm{~cm}$, NT showed greater bacterial diversity than CT (Table 1). In our previous study, at this same layer, microbial biomass-C was $82 \%$ higher in the NT system in comparison to the $\mathrm{CT}$ and also presented a lower value of $q \mathrm{CO}_{2}$ indicating higher microbial metabolic efficiency (BABUJIA et al., 2010). Therefore, the combined results of both studies indicate that, at the $0-5 \mathrm{~cm}$ layer, the NT system has greater bacterial diversity, as well as greater microbial biomass and metabolic efficiency. Altogether, this might contribute to decreases in $\mathrm{CO}_{2}$ emissions (BOND-LAMBERTY; WANG; GOWER, 2004) and increases in soil organic C (BABUJIA et al., 2010).

The lower bacterial diversity in the $0-5 \mathrm{~cm}$ layer under CT (Table 1) might be related to the intense soil disturbance, reducing the macroaggregates that represent important niches for protection and preservation of soil organic matter and microorganisms (LÓPEZ- GUARRIDO et al., 2012). In addition, the redistribution of the residues within the profile with $\mathrm{CT}$ appears to impoverish the superficial layer in $\mathrm{C}$ sources, which might be reflected in decreased diversity of specific groups of microorganisms. For example, it has been reported that the diversity of proteolytic bacteria in an agricultural soil was higher near the surface because of the greater abundance and variety of substrates (FUKA et al., 2009). On the other hand, the lower bacterial diversity with CT does not necessarily mean that soil function will be affected because there may be physiological redundancy (KENNEDY, 2003); however, our results truly show that bacteria are more sensitive than fungi to soil-tillage practices.

Studies indicate that soil type and management system affect the structure of bacterial communities (LÓPEZ- GUARRIDO et al., 2012). In addition, soil depth is a key factor determining the dynamics of soil microorganisms (BABUJIA et al., 2010; WANG; CUI; WANG, 2009); also, diversity of functional groups may be limited with soil depth, as a result of changes in physical and chemical attributes (FRANZLUEBBERS, 2002).

Previous studies show that fungi are more abundant with NT than with CT (WANG et al., 2010). Lower fungal diversity with CT may be explained in terms of the impact of disc plowing, i.e. breaking soil aggregates and fungal hyphae (CORNEJO, YEAR; RUBIO, YEAR; BORIE, 2009; KHIARA et al., 2012). However, our results, especially for the $0-5 \mathrm{~cm}$ layer do not agree with this observation (Table 2). Our findings of higher fungal diversity under CT might be explained by the lower $\mathrm{pH}$ of the NT soil, as previously shown (BABUJIA et al., 2010), and, indeed, Wakalin et al. (2008) suggested that $\mathrm{pH}$ is the strongest factor linked to soil catabolic function and biological community structure. It is well known that fungi have optimal growth in the 2.0 to $7.0 \mathrm{pH}$ range, whereas, for bacteria, the best range is between $\mathrm{pH} 5.0$ and 9.0 (SMITH and DORAN, 1996). Our results are also consistent with a metagenomic analysis in a similar area at the same experimental station, showing greater abundance of fungi with CT than with NT, and the authors suggested that it may be related to higher tolerance of fungi to environmental stresses (SOUZA et al., 2013).

The results from our study confirm that evaluation of microbial communities can provide valuable ecological indicators of soil health, as they are particularly sensitive to external influences and prematurely reflect changes related to disturbance (KASCHUK; ALBERTON; HUNGRIA, 2010; POWLSON, 1994). Our results also emphasize the importance of evaluating not only quantitative but also qualitative microbial parameters to gain better understanding of the effects management practices have on soil quality. 


\section{CONCLUSION}

In a long-term field experiment performed in an Oxisol of southern Brazil, we have shown that bacterial diversity was higher with NT than with CT, especially in the 0-5 cm layer. In contrast, the diversity of fungi was higher in the CT than in the NT system, mainly at the top soil layer.

\section{ACKNOWLEDGMENTS}

L. C. Babujia, A. P. Silva and M. Hungria thank the CNPq (National Council for Scientific and Technological Development) for their $\mathrm{PhD}$, pos-doc and research fellowships, respectively. We thank Dr. Allan R. J. Eaglesham and Dr. Glaciela Kaschuk for review and suggestions on the manuscript. Our special thanks to the Soil Management Team of Embrapa Soja for their efforts in establishing and conducting long-term experiments. Research partially financed by PROBIO II and CNPq Universal (470515/2012-0). Approved for publication by the Editorial Board of Embrapa Soja as manuscript number 003/2014.

\section{REFERENCES}

BABUJIA, L. C. et al. Microbial biomass and activity at various soil depths in a Brazilian oxisol after two decades of no-tillage and conventional tillage. Soil Biology and Biochemistry, v. 43, p. 1-8, 2010.

BALOTA, E. L. et al. Enzimas e seu papel na qualidade do solo. In: ARAÚJO, A.P.; ALVES, B.J.R. (Eds.). Tópicos em Ciência do Solo, Viçosa: Sociedade Brasileira de Ciência do Solo, v. 8, p. 189-249, 2013.

BOND-LAMBERTY, B.; WANG, C. K.; GOWER, S. T. A global relationship between the heterotrophic and autotrophic components of soil respiration? Global Change Biology, v. 10, p. 1756-1766, 2004.

CHAO, A.; LEE, S. M. Estimating the Number of Classes via Sample Coverage. Journal of the American Statistical Association, v. 87, n. 417, p. 210-217, 1992.

CHAO A.; SHEN T. J. 2013. Program SPADE (Species Prediction and Diversity Estimation). Program and user's guide; [accessed 09/2013]. Available from http://chao.stat. nthu.edu.tw.

CORNEJO, P.; RUBIO, R.; BORIE, F. Mycorrhizal propagule persistence in a succession of cereals in a disturbed and undisturbed andisol fertilized with two nitrogen sources. Chilean Journal of Agricultural Research, v. 69, p. 426-434, 2009.

FEBRAPDP (FEDERAÇÃO BRASILEIRA DE PLANTIO DIRETO NA PALHA). Evolução da Área Cultivada no Sistema de Plantio Direto na Palha e Brasil. 2010. Disponível em: $<$ http://febrapdp.org.br/arquivos/EvolucaoAreaPDBr72A06. pdf $>$. Acesso em: out. 2012.

FRANZLUEBBERS, A. J. Soil organic matter stratification ratio as an indicator of soil quality. Soil \& Tillage Research, v. 66, n. 2 , p. $95-106,2002$.

FUKA, M. et al. Changes of diversity pattern of proteolytic bacteria over time and space in an agricultural soil. Microbial Ecology, v. 57, n.3, p. 391-401, 2009.

HANSEL, C. M. et al. Changes in bacterial and archaeal community structure and functional diversity along a geochemically variable soil profile. Applied \& Environmental Microbiology, v. 74, n. 5, p. 1620-1633, 2008.

HUNGRIA M. et al. Preliminary characterization of fast growing strains isolated from soybean nodules in Brazil. Soil Biology \& Biochemistry, v.33, p.1349-1361, 2001.

HUNGRIA, M. et al. Soil microbial activity and crop sustainability in a long-term experiment with three soil tillage and two crop-rotation systems. Applied Soil Ecology, v. 42, n. 3, p. 288-296, 2009.

JOYNT, J. et al. Microbial community analysis of soils contaminated with lead, chromium and organic solvents. Microbiology Ecology, v. 51, p. 209-219, 2006.

KASCHUK, G.; ALBERTON, O.; HUNGRIA, M. Three decades of soil microbial biomass studies in Brazilian ecosystems: lessons learned about soil quality and indications for improving sustainability. Soil Biology \& Biochemistry, v. 42 , p. $1-13,2010$.

KENNEDY, A. C. Bacterial diversity in agroecosystems. Agriculture, Ecosystems and Environmental, v. 170, n. 1, p. 145-156, 2003.

KHIARA, J. et al. Soil aggregation and total diversity of bacteria and fungi in various tillage systems of sub-humid and semi-arid Kenya. Applied Soil Ecology, v. 58, p. 12-20, 2012.

LAL, R. Constraints to adopting no-till farming in developing countries. Soil \& Tillage Research, v. 94, n. 1, p. 1-3, 2007.

LÓPEZ-GUARRIDO, R. et al. Tillage influence on biophysical soil properties: The example of a long-term tillage experiment under Mediterranean rainfed conditions in South Spain. Soil \& Tillage Research, v. 118, p. 52-60, 2012.

MUYZER, G.; WALL, E. C.; UITTERLINDEN, A. G. Profiling of complex microbial populations by denaturing gradient gel electrophoresis analysis of polymerase chain reactionamplified genes coding for 16S rRNA. Applied and Enviromental Microbiology, v. 59, n. 3, p. 695-700, 1993.

NAKATANI, A. S. et al. Changes in the genetic structure of bacteria and microbial activity in an agricultural soil amended with tannery sludge. Soil Biology \& Biochemistry, v. 43, p. 106-114, 2011.

NÜBEL, U. et al. Sequence heterogeneities of genes encoding 16S rRNAs in Paenibacillus polymyxa detected 
by temperature gradient gel electrophoresis. Journal of Bacteriology, v. 178, n. 19, p. 5636-5643, 1996.

POWLSON, D. S. The soil microbial biomass: before, beyond and back. In: K. RITZ, J.; DIGHTON, K. E. GILLER (Eds.), Beyond the Biomass, Chichester, NY, 1994, pp. 3-20.

SHANNON, C. E.; WEAVER, W. The Mathematical Theory of Communication. Urbana: University of Illinois Press, 1963. 173 p.

SILVA, A. P. et al. Microbial biomass under various soiland crop- management systems in short- and long- term experiments in Brazil. Field Crops Research, v. 119, p. 2026, 2010 .

SILVA, A. P. et al. Bacterial diversity under different tillage and crop rotation systems in an Oxisol of southern Brazil. The Open Agriculture Journal, v. 7, p. 40-47, 2013.

SMITH, J. L.; DORAN, J. W. Measurement and use of $\mathrm{pH}$ and electrical conductivity for soil quality analysis. In Methods for assessing soil quality. Soil Science Society of America Special Publication, v. 49, p. 169-182, 1996.

SMIT, E. et al. Analysis of fungal diversity in the wheat rhizosphere by sequencing of cloned PCR-amplified genes encoding 18S rRNA and temperature gradient gel electrophoresis. Applied and Environmental Microbiology, v. 65, p. 2614-2621, 1999.

SNEATH, P. H. A.; SOKAL, R. R. Numerical taxonomy: the principles and practice of numerical classification. San Francisco: W. H. Freeman, 1973. 573 p.
SOUZA, R. C. et al. Soil metagenomics reveals differences under conventional and no-tillage with crop rotation or succession. Applied Soil Ecology, v. 72, p. 49-61, 2013.

WAKELIN, S. A. et al. Habitat selective factors influencing the structural composition and functional capacity of microbial communities in agricultural soils. Soil Biology \& Biochemistry, v. 40, p. 803-813, 2008.

WANG, J. Z.; CUI, L. J.; WANG, Y. Growth, lipid peroxidation and photosynthesis in two tall fescue cultivars differing in heat tolerance. Biologia Plantarum, v. 53, n. 2, p. 237-242, 2009.

WANG, Y. et al. Tillage, residue burning and crop rotation alter soil fungal community and water-stable aggregation in arable fields. Soil \& Tillage Research, v. 107, p. 71-79, 2010 .

WARDLE, D. A. Is "sampling effect" a problem for experiments investigating biodiversity-ecosystem function relationships? Oikos, v. 8, p. 403-407, 1999.

WEISBURG, W. G. et al. 16S ribosomal DNA amplification for phylogenetic study. Journal of Bacteriology, v. 173, n. 2, p. 697-703, 1991.

WHITE, T. J. et al. Analysis of phylogenetic relationships by amplification and direct sequencing of ribosomal RNA genes. In: INNIS, M. A.; GELFAND, D. H.; SNINSKY, J. J.; WHITE, T. J. (Eds.). PCR protocols: a guide to methods and applications. New York: Academic Press, 1990. p. 315322. 